\title{
Experimental Behavior of Masonry Arches with and Without Fiber Reinforced Polymer
}

\author{
R.Chitra, S.Thendral, S.J.Mohan
}

\begin{abstract}
This paper deals with the experimental behavior of solid clay brick masonry parabolic arches. Among all the different structural systems, masonry arches are the most efficient. In this paper preliminary tests were carried out on cement, sand, bricks, mortar and their material properties like specific gravity for cement, sand, compression strength on bricks, mortar and water absorption test on bricks, were studied. In this report fabrication of masonry arch of same dimensions were carried out. A total of four specimens were casted out of which two specimens were casted without GFRP. and two other were wrapped with GFRP on extrados and intrados surface of the arch. Specimens are having the span of $1.3 \mathrm{~m}$, rise of 0.5 and width of $0.230 \mathrm{~m}$. After the casting and curing of the all specimens was carried out, two arches which are without glass fiber reinforced polymer are subjected to monotonic loading and then other two arches were wrapped with glass fiber reinforced polymer and then subjected to monotonic loading
\end{abstract}

Keywords : unreinforced and reinforced arch, parabolic arch, local failure, parabolic equation, loading conditions, Gfrp, ANSYS

\section{INTRODUCTION}

An arch is a mechanical arrangement of wedge shaped blocks of bricks or stones supporting each other and supported at the end by abutments. It is actually an aciform which is not really known for their load bearing capability but has an aesthetic, historic, cultural and architectural importance. [2 ],[4],[6]

The history and appearance of arches dates back to 2nd millennium (B.C) Mesopotamia as brick architecture and their efficient and methodic adoption started in Ancient Rome where they applied the technique to a wider range of architectural masterpieces. Arches are known to have lesser tensile strengths and to eliminate the stress it spans over a large area and resolves the forces in such a way that the tensile stress is relieved. This is often called as arch-action. As the force is applied on the arch towards the ground, there is a resultant outward push at the base by the arch referred to as thrust. As the height of the arch decreases, the thrust increases outwards. To prevent the collapse of the arch we

Revised Manuscript Received on July 22, 2019

RChitra, Deparment of Civil Engineering, Bharath Institute of Higher Education and Research, Tamilnadu,India. Email: chitraroopauma@gmail.com

S.Thendral, Deparment of Civil Engineering, Bharath Institute of Higher Education and Research, Tamilnadu,India. Email: thendral.cs@gmail.com

Dr.S.J.Mohan, Deparment of CivilEngineering, Bharath Institute of Higher Education and Research, Tamilnadu,India. Email: mohansjm@yahoo.com need to arrest the thrust action either by internal ties else external bracing, for example by using abutments. Such a structure (arch) is said to be in the form of pure compression and the building materials of an arch like stone and concrete (unreinforced) are able to resist the compression but not tensile stress. The weight of all the constituents is responsible to hold the arch in place, making it problematic to construct an arch. One of the solutions is to construct a frame prior to the construction of an arch resembling exactly the underside of the arch, commonly known as the centering. Until the structure is self-supporting and accomplished Voussoirs are used on it and scaffolding is done for the arches that are higher than the head-height in combination with the structure support. At times the arch would fall down if the frame was dislodged or if the construction be been faulty, as it happened to the A85 Bridge at Scotland in 1940's on its very first attempt. The interior curve of an arch is called as intrados. The old arches often need reinforcements because of the decay of keystones, forming bald arches. The main principle used in the construction of reinforced concrete arches is the strength and stability of the concrete, resisting stress of compression. If the tensile stress or any other kind of stress is increased, the resistance is to be increased by placing reinforcement-rods or reinforcement fibers. Mainly three types of arches are used in practice: three-hinged, two-hinged and hinge less arches.

\section{METHODOLOGY}

\section{A. Materials}

Cement, sand, bricks and iron rods(which are used to make the steel moulds). In this project the four specimens were casted with span $1.3 \mathrm{~m}$, rise $0.5 \mathrm{~m}$, and thickness $0.23 \mathrm{~m}$ as per the dimensions of brick out of which two arches were without GFRP and two with GFRP. The materials used for wrapping of GFRP on arches were G.P resin, woven fibre, normal fibre accelerator, catalyst \& pigment[13], [15] ,[ 17]

\section{B. Preparation of steel mould}

The mould used for the constructing the arches were made of steel. Same dimensions of steel moulds were used for the entire project. Steel Mould of dimensions of span $=1.3 \mathrm{~m}$, rise $=0.5 \mathrm{~m}$ and width $=0.23 \mathrm{~m}$ were used. The coordinates of the along the $\mathrm{x}$ and $\mathrm{y}$ axis are: 


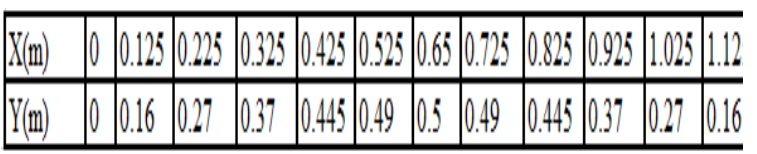

\begin{tabular}{|cl|ll|ll|ll|ll|}
\hline$[1]$ & $\begin{array}{l}\text { Value } \\
\text { of } \\
\mathrm{x}(\mathrm{m})\end{array}$ & {$[2]$} & 0.162 & {$[3]$} & 0.325 & {$[4]$} & 0.425 & {$[5]$} & 0.475 \\
\hline$[6]$ & $\begin{array}{l}\text { Value } \\
\text { of }(\theta)\end{array}$ & {$[7]$} & 61.73 & {$[8]$} & 56 & {$[9]$} & 52.22 & {$[10]$} & 38.97 \\
\hline
\end{tabular}

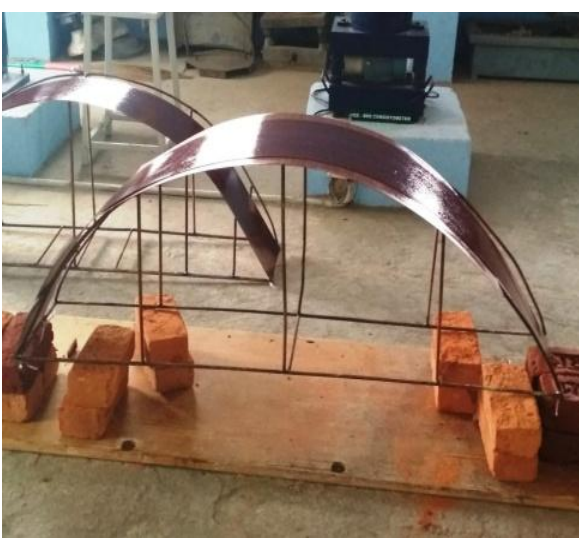

Fig 1: Preparation of steel mould

the mould is prepared as per the coordinates obtained from the design of parabolic curve. The parabolic curve is designed from the equation of parabola and after deriving the mathematical equation we got the coordinates and from those coordinates we got the rise along $y$ axis with respective distances from $\mathrm{x}$ axis

\section{Design for parabolic curve}

The mould used for the constructing the arches was made of steel. Same dimensions of steel moulds were used for the entire project . Steel Mould of dimensions of span $=1.3 \mathrm{~m}$, rise $=0.5 \mathrm{~m}$ and width $=0.23 \mathrm{~m}$ were used.

$$
\begin{gathered}
\mathrm{Y}=\mathrm{ax} \mathrm{x}^{2} \mathrm{bx} \\
\text { At } \mathrm{a}=0.325 \\
0.5=0.105 \mathrm{a}+0.325 \mathrm{~b} \ldots \ldots \ldots \ldots \ldots \\
\text { At } \mathrm{x}=0.975 \\
0.5=0950 \mathrm{a}+0975 \mathrm{~b} \ldots \ldots \ldots \ldots \\
\text { From } 1 \text { and } 2 \\
\mathrm{a}=0.5263-1.026 \mathrm{~b} \\
\text { put the value of a in } 1 \\
\mathrm{~b}=2.2 \\
\mathrm{a}=-1.7 \\
\mathrm{Y}=-1.7 \mathrm{x}^{2}+2.2 \mathrm{x} \\
\frac{d y}{d x}=-2.14 \mathrm{x}+2.2 \\
\text { At } \mathrm{x}=0.325 \\
\text { Tan } \theta=1.5 \\
\theta=56^{0} \\
\text { at } \mathrm{x}=0.425 \\
\theta=52.22^{0} \\
\text { at } \mathrm{x}=0.162 \\
\theta=61.73^{0} \\
\text { at } \mathrm{x}=0.525 \\
\theta=47^{\circ}
\end{gathered}
$$$$
0.5=0.105 \mathrm{a}+0.325 \mathrm{~b} \ldots \ldots \ldots \ldots \ldots \ldots \ldots .1
$$

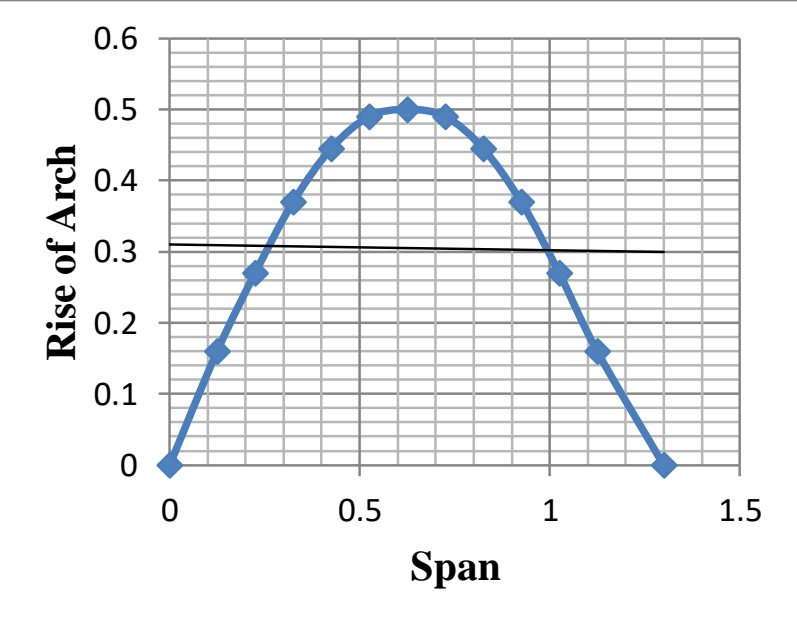

Fig 2: Parabolic curve (plotting the $x$ and $y$ coordinates)

\section{A. Design of parabolic arch}

The horizontal thrust of a parabolic arch is given by the general formula;

$$
H=\frac{\int \frac{M Y}{E I} d s}{\int \frac{Y^{2}}{E I} d s}
$$

value of the $m=V_{a} \cdot x-\sum m x$

where $\mathrm{m}$ is the moment at a distance $\mathrm{x}$ from the support

\section{A. When the load is at crown}

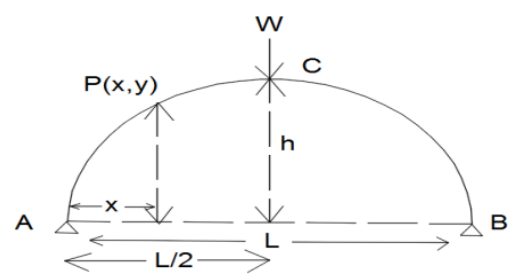

As $\mathrm{H}=\frac{\int M y d x}{\int y^{2} d x}$

Taking first part of integral

$$
\text { 1. } \begin{aligned}
\int_{0}^{l} M y d x & =2 \int_{0}^{l} M y d x \\
\mathrm{M} & =\frac{W}{2} x \\
\mathrm{Y} & =\frac{4 h x(l-x)}{l^{2}}
\end{aligned}
$$




$$
\begin{gathered}
\int_{0}^{l} M y d x=2 \int_{0}^{l} \frac{w}{2} x \cdot \frac{4 h}{l^{2}} x(l-x) d x \\
=\frac{4 w h}{l 2}\left[\frac{l x 3}{3}-\frac{x 4}{4}\right] \frac{l}{2} \\
=\frac{4 w h}{l 2} l 4\left[\frac{1}{24}-\frac{1}{64}\right] \\
\int_{0}^{l} M y d x=\frac{5}{48} w h l^{2} \quad 2^{\text {nd }} \text { part of integral is } \\
\int_{0}^{l} y 2 d x=2 \int_{0}^{\frac{l}{2}} \frac{16 h 2}{l 4} x 2(l-x) 2 d x \\
=\frac{32 h 2}{l 4} \int_{0}^{\frac{l}{2}} x 2(l-x) 2 d x \\
=\frac{32 h 2}{l 4}[x 2(l-x) 2 d x] \\
=\frac{32 h 2}{l 4}\left(\frac{l^{2} x^{3}}{3}+\frac{x^{5}}{5}-\frac{2 l \cdot x^{4}}{4}\right) \\
\int_{0}^{\frac{l}{2}} y^{l / 2} d x=\frac{8}{15}\left(\frac{h^{2}}{l}\right) \\
\left.y_{0}^{2}\right)
\end{gathered}
$$

As per the general equation of the parabola , the horizontal thrust for the load acting at the crown is given by dividing the ist integral by the second integral

$$
\begin{aligned}
\mathrm{H}=\frac{\frac{5}{128} W h l^{2}}{\frac{8}{15}\left(h^{2} l\right)} \\
\mathrm{H}=\frac{5}{128} \frac{W l}{h}
\end{aligned}
$$

Where $h$ is the rise of arch and 1 is the total span of arch.

This is the required expression for the horizontal thrust when the load is acting on crown

Where $h$ is the rise of arch and 1 is the total span of arch

\section{When concentrated load acting on arch}

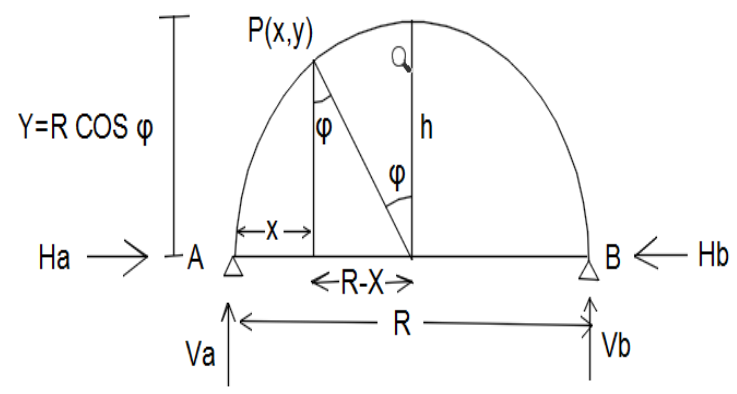

The concentrated load acting on a arch is given by In above fig

$$
\begin{gathered}
\mathrm{Y}=\mathrm{R} \cos \Phi \\
\mathrm{R}-\mathrm{x}=\mathrm{R} \sin \Phi \\
\mathrm{X}=\mathrm{R}-\mathrm{R} \sin \Phi \\
\mathrm{X}=\mathrm{R}(1-\sin \Phi) \\
\mathrm{d} \Phi=\frac{d s}{d r} \\
\mathrm{ds}=\mathrm{Rd} \Phi \\
\text { now } \int M y d s=\frac{W R^{3}}{3} \\
\int Y^{2} d s=2 \int_{0}^{\frac{\pi}{2}} R^{2} \cos ^{2} \emptyset \mathrm{R} \mathrm{d} \Phi \\
=2 R^{3} \int_{0}^{\frac{\pi}{2}} \cos ^{2} \Phi d \Phi
\end{gathered}
$$

$$
\begin{gathered}
=2 R^{3} \int_{0}^{\frac{\pi}{2}} \frac{\left(1+\cos ^{2} \Phi\right)}{2} d \Phi \\
=R^{3}\left\{\frac{\pi}{2}-0\right\} \\
=\pi \frac{R^{3}}{2}
\end{gathered}
$$

Therefore horizontal thrust will be

$$
\mathrm{H}=\frac{W}{\pi}
$$

At any angle value $=\theta$

$$
\mathrm{H}=\frac{W}{\pi} \operatorname{Cos}^{2}
$$

In case if the load acting is distributing load ,then the normal and tangential shear will occur

$$
\begin{aligned}
N_{\text {shear }} & =V_{p} \cos \theta-H_{p} \sin \theta \\
T_{\text {shear }} & =V_{P} \sin \theta+H_{P} \cos \theta
\end{aligned}
$$

\section{A. Calculation Of Ordinate Points Of $\mathbf{P}\left(\mathbf{x}_{1} \mathbf{y}_{1}\right)$,}

$P\left(x_{2} y_{2}\right), P\left(x_{3} y_{3}\right), P\left(x_{4} y_{4}\right)$, and $P\left(x_{5} y_{5}\right)$.

The values of ordinates can be calculated by the equation of parabola

$$
\begin{gathered}
y_{1}=\frac{4 \times 0.5 \times 0(1.3-0)}{1.3^{2}} \\
y_{1}=0 \\
y_{2}=\frac{4 \times 0.5 \times 0.125(1.3-0.125)}{1.3^{2}} \\
y_{3}=\frac{4 \times 0.5 \times 0.225(1.3-0.225)}{1.3^{2}} \\
y_{4}=\frac{4 \times 0.5 \times 0.325(1.3-0.325)}{1.3^{2}} \\
y_{5}=\frac{4 \times 0.5 \times 0.425(1.3-0.425)}{1.3^{2}} \\
y_{5}=\frac{4 \times 0.5 \times 0.525(1.3-0.525)}{1.3^{2}} \\
y_{6}=\frac{4 \times 0.5 \times 0.650(1.3-0.650)}{1.3^{2}} \\
y_{6}=0.5
\end{gathered}
$$

A. Casting Of Arches

The arches were casted with the same dimensions which were obtained as per design criteria in which the span of arch is $1.3 \mathrm{~m}$ width of arch is $0.23 \mathrm{~m}$ and rise of arch is $0.5 \mathrm{~m}$. The thickness of the arch is as per the thickness of the brick dimensions which is $0.110 \mathrm{~m}$. [20],[ 22], [24]

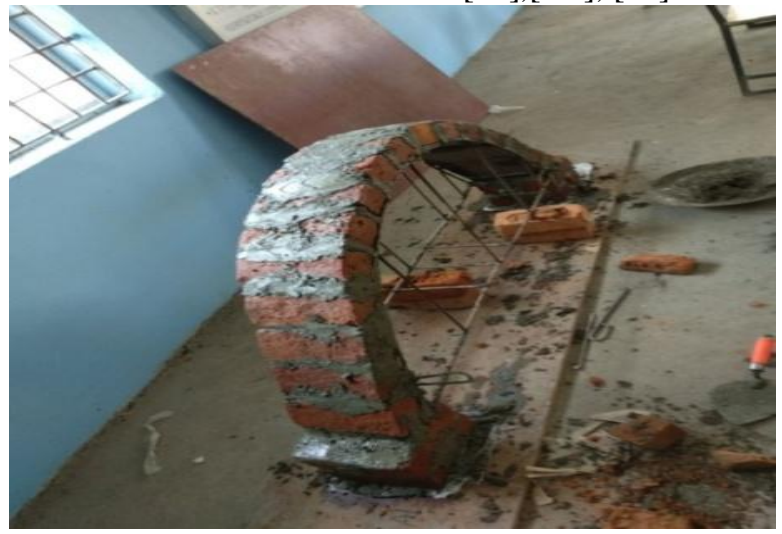

Fig 3: Casting of brick arch 


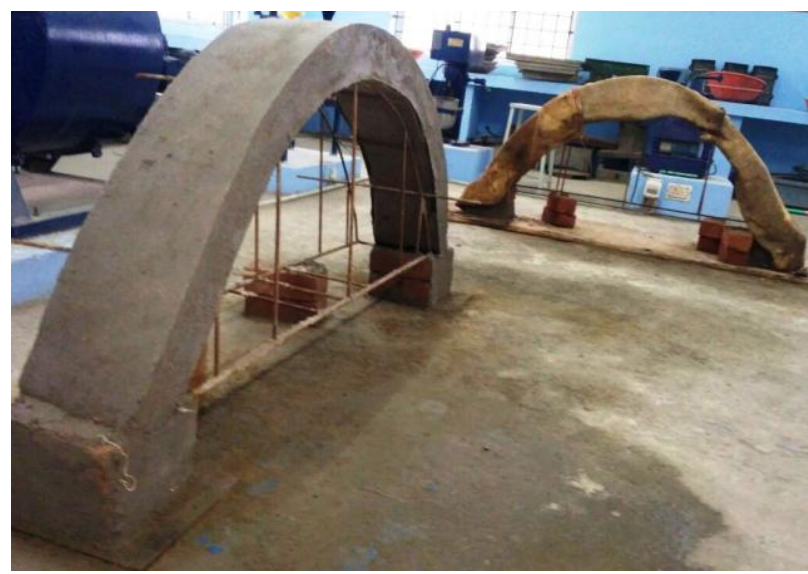

Fig 4: Casting of brick arch

\section{A. Application of GFRP on arches}

The application of the strengthening was carried out on the arches. In the strengthening phase, three arches were casted and one arch is wrapped with GFRP on intrados and extrados surfaces. Two types of polymers were used for strengthening. All rough spots were cleaned up and then the two adhesives were prepared one adhesive was prepared with Araldite AW 106 epoxy and HV 953 hardener and other with resin of 1 liter mixed with $20 \mathrm{~g}$ of catalyst and accelerator and then it was mixed properly to make it a paste. After that, a thin layer was applied on the intrados and extrados surface. The specimen was left to dry for 48 hours.

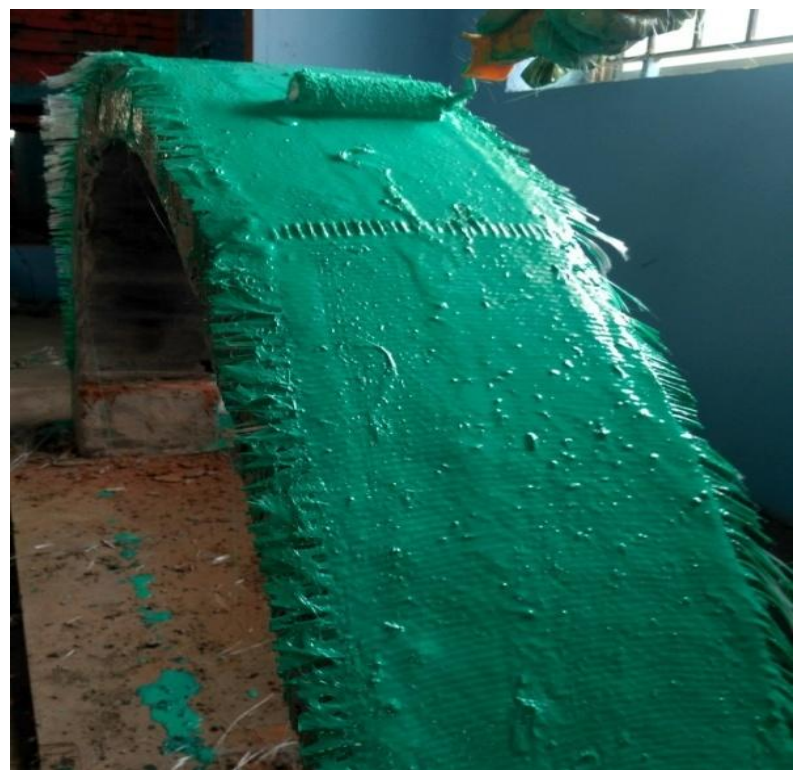

Fig 5: Application of GFRP on extrados

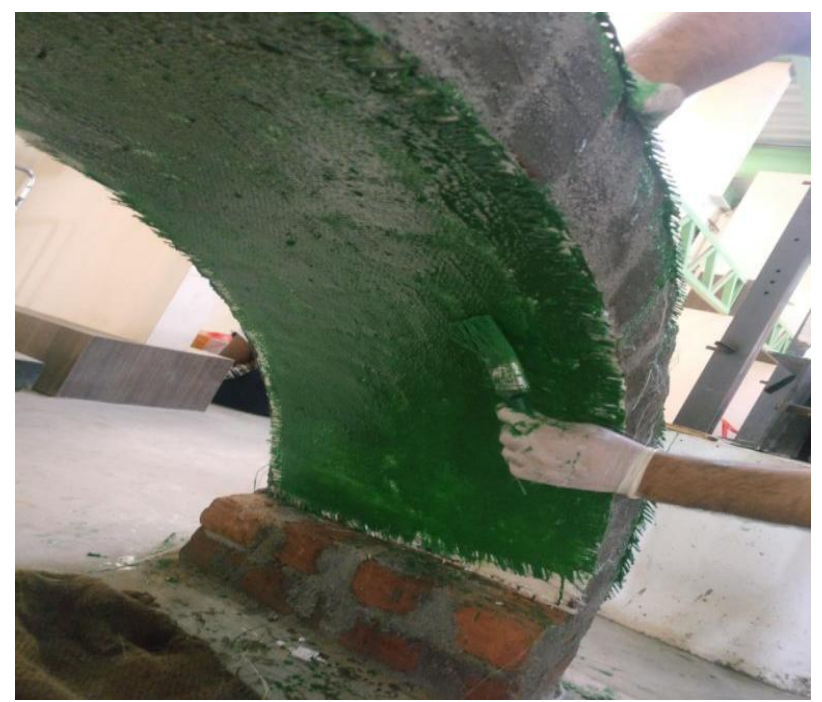

Arches are placed on loading frame and subjected to central concentrated force and the corresponding deflections are measured within the elastic range using data logger. $[26],[28],[30]$

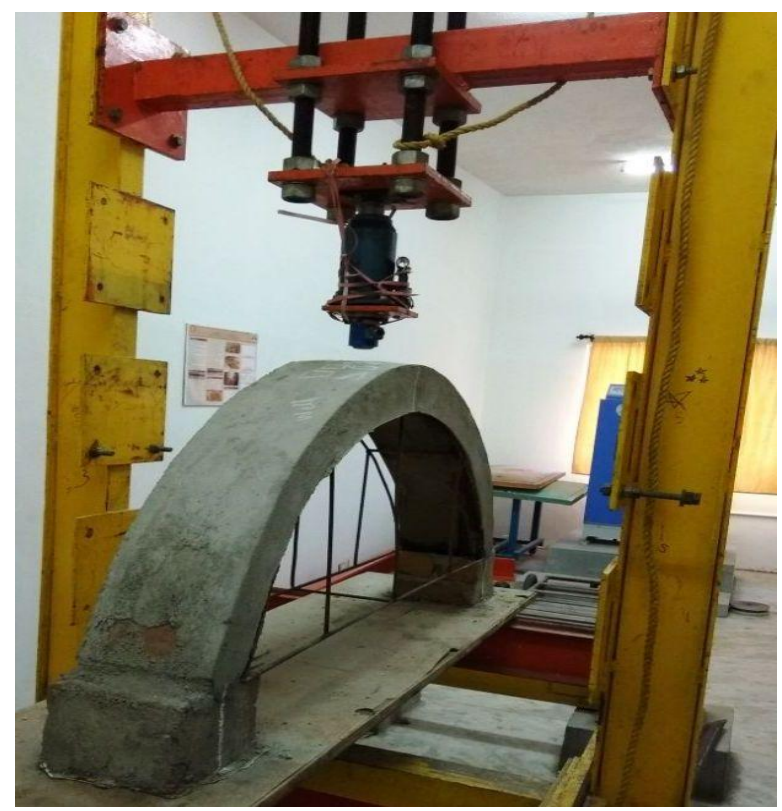

Fig 7: Loading Frame \& Hydraulic jack attached to arch 


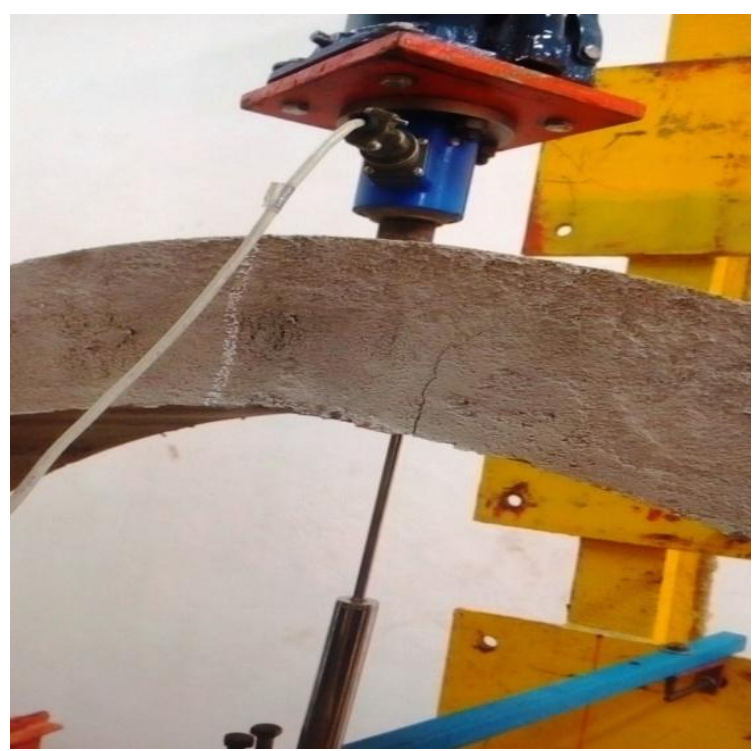

Fig 8: Initial cracks on arch

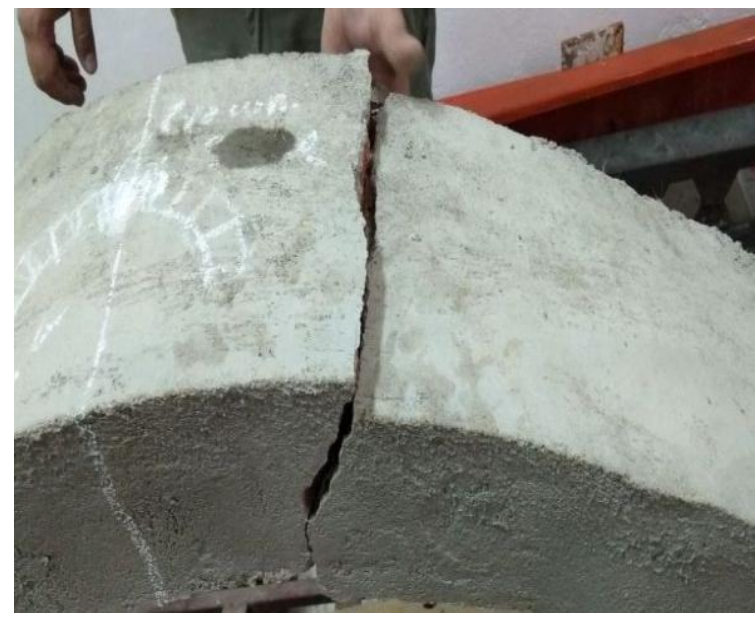

Fig 9: Major crack on arch

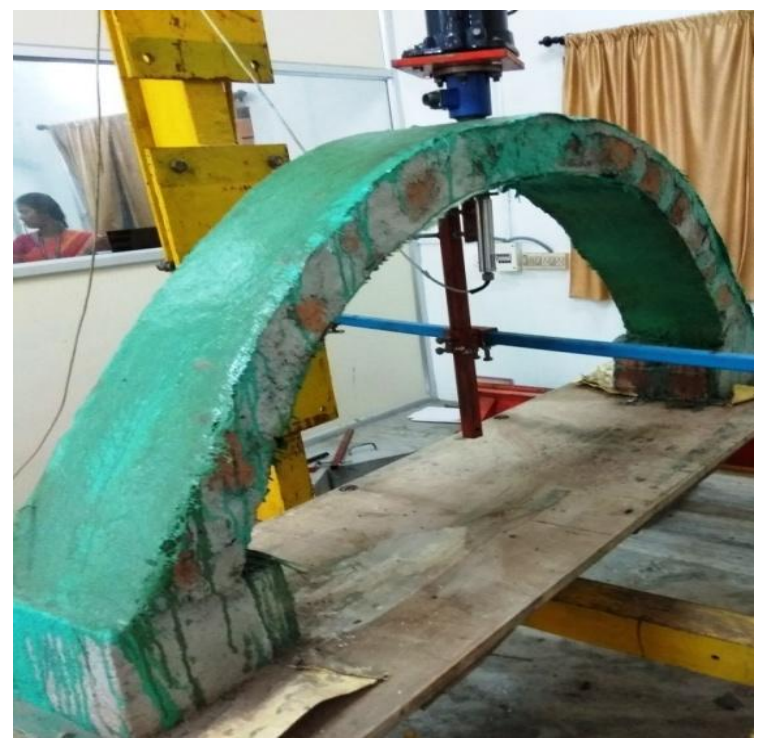

Fig 10: Testing of GFRP arches

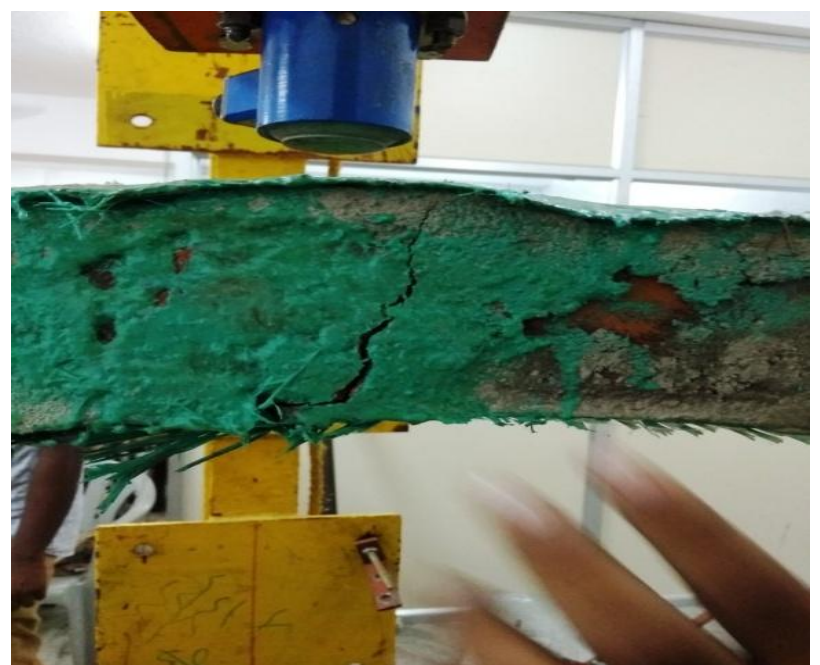

Fig 11: crack pattern on GFRP arches

Failure is defined as the point when the specimen can no longer bear the load and the specimen collapses. The arches failed at crown point.

\section{RESULTS AND DISCUSSIONS}

\section{Experimental Analysis Of Arches Without Gfrp}

The $1.3 \mathrm{~m}$ span arches were fabricated with 20 brick courses and characterised by a rise of $0.5 \mathrm{~m}$, width of $0.23 \mathrm{~mm}$ and thickness of $0.110 \mathrm{~mm}$. All the arches were built over a strong rigid steel frame. All the specimens were tested, which presented a similar structural behaviour, essentially characterised by the development of three hinge mechanism. The parameters of the arches were checked. The main things we can get from the testing are - load-deflection characteristics of a specimen and modes of failure. Load vs. deflection of the three specimens are given below;- [13], [15] ,[17]

\section{A. LOAD VS DEFLECTION BEHAVIOUR OF 1.3 M SPAN ARCH (1).}

An ultimate load for $1.3 \mathrm{~m}$ span arch was found to be $6 \mathrm{kN}$ experimentally with a maximum deflection of 0.42

Table 1: LOAD VS DEFLECTION

\begin{tabular}{|c|c|}
\hline $\begin{array}{c}\text { LOAD } \\
(\mathbf{K N})\end{array}$ & DEFLECTION (mm) \\
\hline 0 & 0 \\
\hline 1 & 0.05 \\
\hline 2 & 0.09 \\
\hline 3 & 0.14 \\
\hline 4 & 0.22 \\
\hline 5 & 0.35 \\
\hline 6 & 0.42 \\
\hline
\end{tabular}




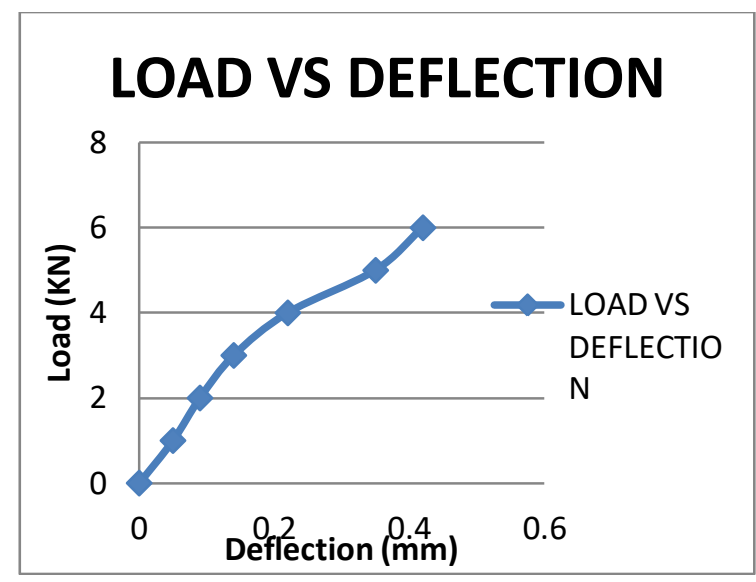

Fig 7: Graph showing load v/s deflection curve

\section{A. Load Vs Deflection Curve For 1.3m Span Arch (2);-}

An ultimate load for $1.3 \mathrm{~m}$ span arch was found to be $6 \mathrm{kN}$ experimentally with a maximum deflection of 0.43 .

\begin{tabular}{|c|c|} 
Table 2: LOAD VS DEFLECTION \\
$\begin{array}{c}\text { LOAD } \\
(\text { KN) }\end{array}$ & DEFLECTION (mm) \\
\hline 0 & 0 \\
\hline 1 & 0.06 \\
\hline 2 & 0.10 \\
\hline 3 & 0.15 \\
\hline 4 & 0.23 \\
\hline 5 & 0.36 \\
\hline 6 & 0.43 \\
\hline
\end{tabular}

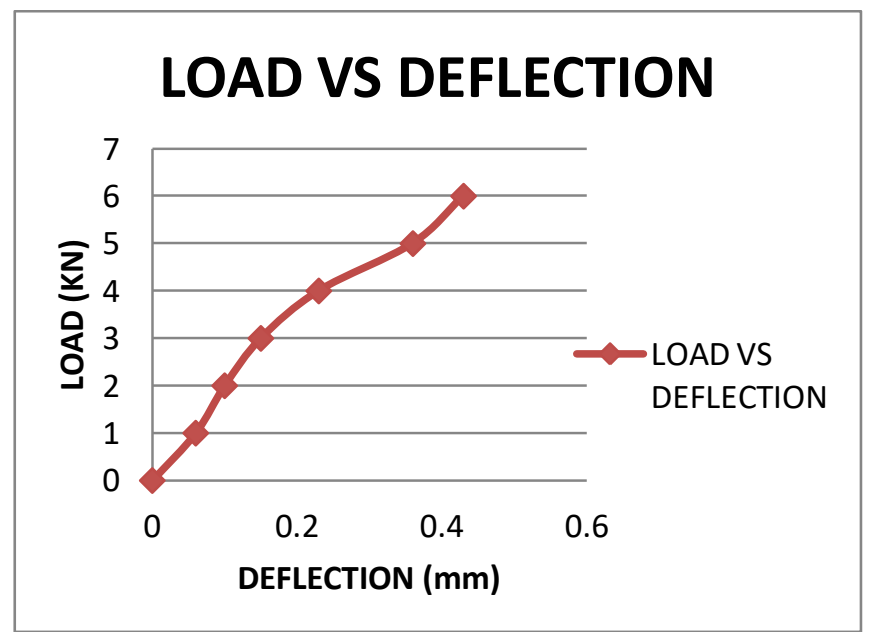

Fig 8: Graph Showing Load Vs Deflection

A. Combined Load Vs Deflection Curve For $1.3 \mathrm{~m}$ Span Arches ;-

The Mean load carrying capacity of the arches without GFRP is $6 \mathrm{KN}$ with a mean deflection of $0.425 \mathrm{~mm}$ and the mean stiffness of the arches without GFRP was found to be $14.115 \mathrm{KN} / \mathrm{mm}$ also the failure of the arches was found to be three hinged experimentically.

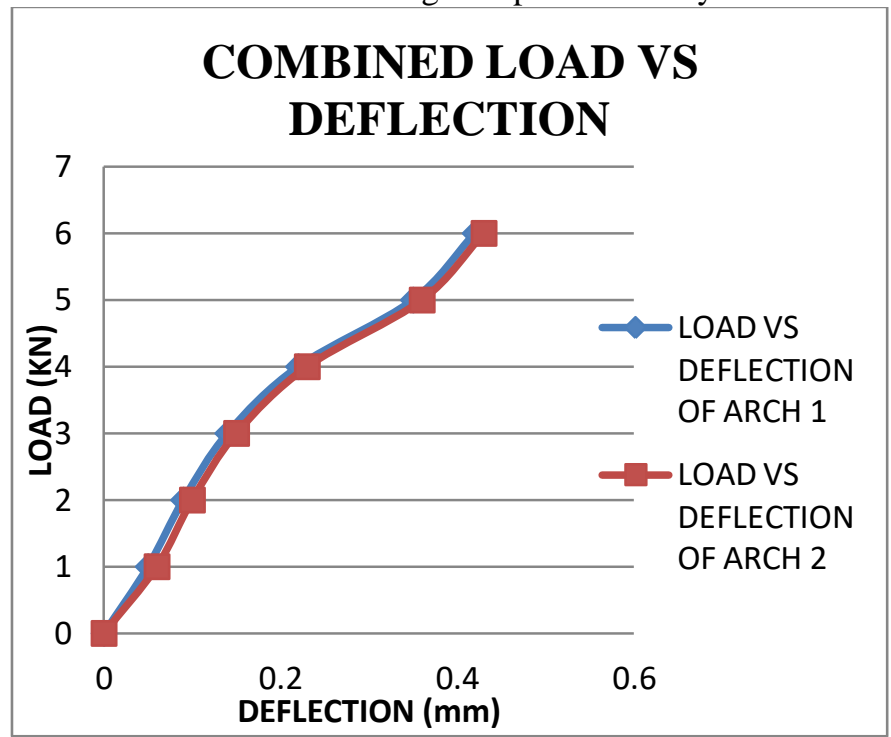

Fig 9: Combined graph showing Load Vs Deflection

Analytical Analysis Of Arches Without Gfrp By Ansys With the help of ANSYS WORKBENCH 3D models were prepared of dimension $1.3 \mathrm{~m}$ span, rise of $0.5 \mathrm{~m}$, width of $0.23 \mathrm{~m}$ and thickness $0.110 \mathrm{~m}$. An extra layer of $1 \mathrm{~mm}$ in thickness was added to intrados and extrados surfaces. Load applied to the arch was monotonic load at the crown and in the center. Properties like poisons ratio and young's modulus were applied.

Analytically it is found that the total deformation of the arch was found out to be $0.42 \mathrm{~mm}$.

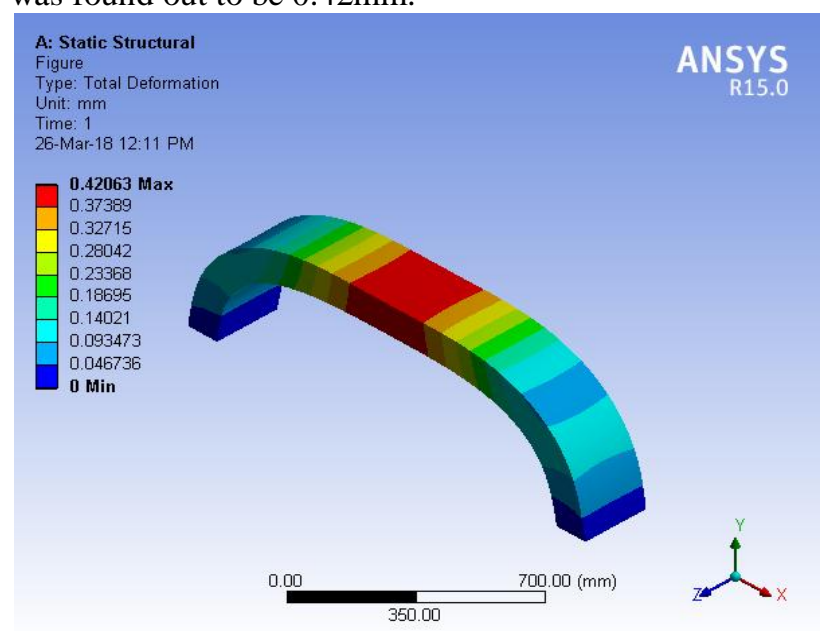

Fig 10: Analytical analysis of arch without GFRP

Experimental Analysis Of Arches With Gfrp

Masonry Arches were strengthened by GFRP wrapped on the intrados and extrados surfaces. All the specimens were tested under monotonic loading. The Parameters for the arches were checked. The major areas of interest are load - deflection characteristics of the specimen. Load v/s deflection of specimens are shown below

Published By: 


\section{A. Load Vs Deflection Curve Of Arch Of Span 1.3m} With Gfrp

An ultimate load of $13 \mathrm{KN}$ was achieved for $1.3 \mathrm{~m}$ span of arch with a maximum deflection of $0.12 \mathrm{~mm}$

Table 3: LOAD VS DEFLECTION

\begin{tabular}{|c|c|}
\hline LOAD(KN) & DEFLECTION(mm) \\
\hline 0 & 0 \\
\hline 1 & 0.01 \\
\hline 2 & 0.02 \\
\hline 3 & 0.03 \\
\hline 4 & 0.03 \\
\hline 5 & 0.04 \\
\hline 6 & 0.04 \\
\hline 7 & 0.05 \\
\hline 8 & 0.06 \\
\hline 9 & 0.07 \\
\hline 10 & 0.08 \\
\hline 11 & 0.10 \\
\hline 12 & 0.11 \\
\hline 13 & 0.12 \\
\hline
\end{tabular}

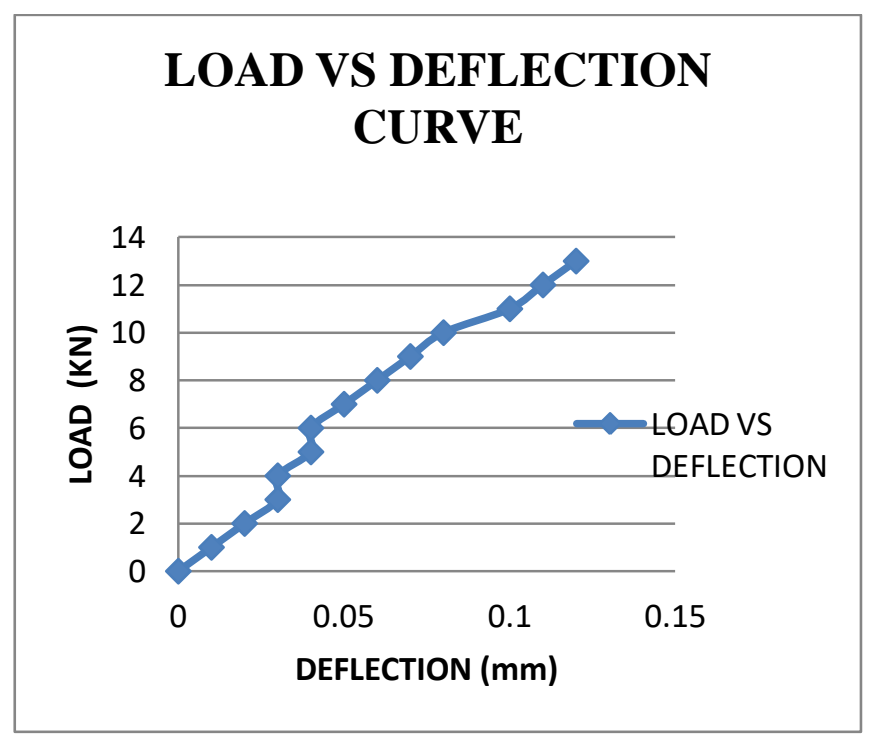

FIG 11 LOAD VS DEFLECTION CURVE

Table 4: LOAD VS DEFLECTION

\begin{tabular}{|c|c|}
\hline LOAD $(\mathbf{K N})$ & DEFLECTION(mm) \\
\hline 0 & 0 \\
\hline 1 & 0.01 \\
\hline 2 & 0.02 \\
\hline 3 & 0.03 \\
\hline 4 & 0.03 \\
\hline 5 & 0.04 \\
\hline 6 & 0.04 \\
\hline 7 & 0.05 \\
\hline 8 & 0.05 \\
\hline
\end{tabular}

\section{FIG 12 LOAD VS DEFLECTION CURVE}

B. Combined Graph Of The Arches With Gfrp

The Mean load carrying capacity of the arches without GFRP is $12.5 \mathrm{KN}$ with a mean deflection of $0.11 \mathrm{~mm}$ and the mean stiffness of the arches without GFRP was found to be $108.33 \mathrm{KN} / \mathrm{mm}$.

\section{COMBINED LOAD VS DEFLECTION OF ARCHES WITH GFRP}

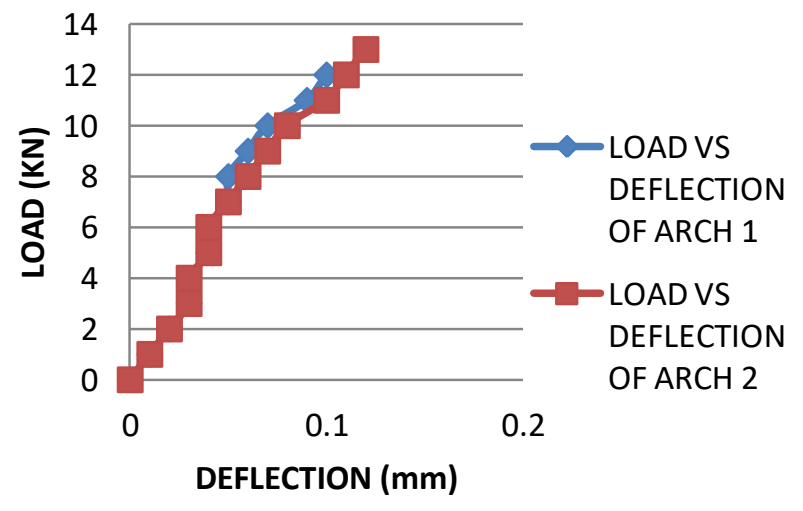

FIG 13 LOAD VS DEFLECTION CURVE

Analytical Analysis Of Arches With Gfrp By Ansys

With the help of ANSYS WORKBENCH 3D models were prepared of dimension $1.3 \mathrm{~m}$ span, rise of $0.5 \mathrm{~m}$, width of $0.23 \mathrm{~m}$ and 
thickness $0.110 \mathrm{~m}$. An extra layer of $1 \mathrm{~mm}$ in thickness was added to intrados and extrados surfaces. Load applied to the arch was monotonic load at the crown and in the center. Properties like poisons ratio and young's modulus were applied. Analytically it is found that the total deformation of the arch was found out to be $0.14 \mathrm{~mm}$.

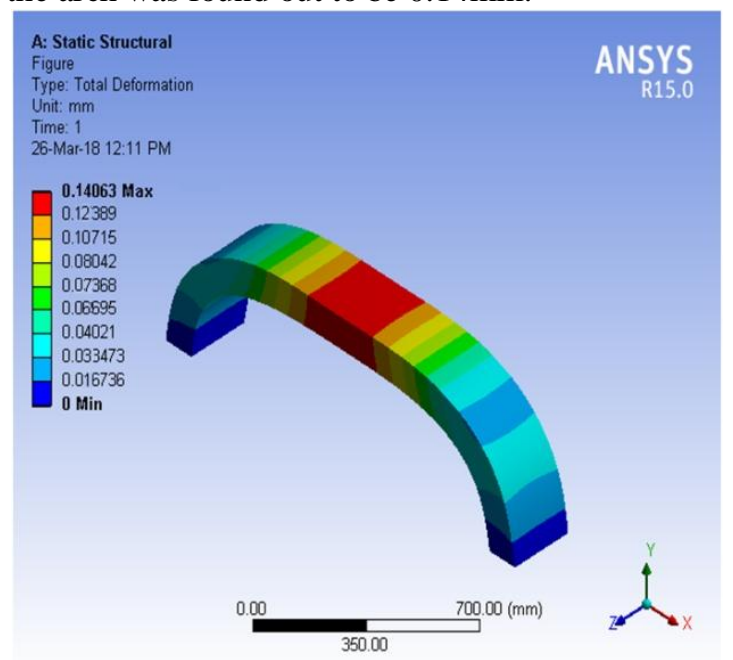

FIG 14 Analytical analysis of GFRP arch by ANSYS

\section{CONCLUSION}

Based on the experimental investigation, it can be concluded that

1. An ultimate load of $6 \mathrm{kN}$ was achieved for $1.3 \mathrm{~m}$ span of arch 1 without GFRP (glass fiber reinforced polymer) with a maximum deflection of $0.42 \mathrm{~mm}$.

2. An ultimate load of $6 \mathrm{kN}$ was achieved for $1.3 \mathrm{~m}$ span of arch 2 without GFRP (glass fiber reinforced polymer) with a maximum deflection of $0.43 \mathrm{~mm}$.

3. Mean load carrying capacity of the arches without GFRP is $6 \mathrm{KN}$ with a mean deflection of $0.425 \mathrm{~mm}$.

4. An ultimate load of $13 \mathrm{KN}$ was achieved for $1.3 \mathrm{~m}$ span of arch 1 with GFRP (glass fiber reinforced polymer) with a maximum deflection of $0.12 \mathrm{~mm}$.

5. An ultimate load of $12 \mathrm{KN}$ was achieved for $1.3 \mathrm{~m}$ span of arch 2 with GFRP (glass fiber reinforced polymer) with a maximum deflection of $0.10 \mathrm{~mm}$.

6. The mean load carrying capacity of the GFRP arches was found to be $12.5 \mathrm{KN}$ with a maximum mean deflection of $0.11 \mathrm{~mm}$

7. It can be concluded that by application of GFRP on the arches the load carrying capacity is increased by $48 \%$ for span of $1.3 \mathrm{~m}$ arch.

8. Mode of failure of the arches was found to be three hinged.

9. Stiffness of the arch for experimental test was found out to be $14.11 \mathrm{KN} / \mathrm{mm}$ for $1.3 \mathrm{~m}$ arch span which is without GFRP (glass fiber reinforced polymer).

10. Stiffness of the arch for experimental test was found out to be $108.33 \mathrm{KN} / \mathrm{mm}$ for $1.3 \mathrm{~m}$ arch span which is with GFRP (glass fiber reinforced polymer).
11. It can be concluded that stiffness of the GFRP arches are 7.5 times more than the stiffness of the arches without GFRP.

12. It is concluded by experimentally that with increase in span, ultimate load carrying capacity of the arch decreases and vice versa.

13. The total deformation of the arch without GFRP (glass fiber reinforced polymer) as per ANSYS is $0.4206 \mathrm{~mm}$.

14. The total deformation of the arch with GFRP (glass fiber reinforced polymer) as per ANSYS is $0.1406 \mathrm{~mm}$.

\section{REFERENCES}

1.Iyappan L., Dayakar P., Identification of landslide prone zone for coonoortalukusing spatial technology, International Journal of Applied Engineering Research,V-9,I-22,PP-5724-5732,Y-2014.

2.Kumar J., Sathish Kumar K., Dayakar P.,Effect of microsilica on high strength concrete, International Journal of Applied Engineering Research,V-9,I-22,PP-5427-5432,Y-2014.

3.Dayakar P., Vijay Ruthrapathi G., Prakesh J., Management of bio-medical waste, International Journal of Applied Engineering Research,V-9,I-22,PP-5518-5526,Y-2014.

4.Swaminathan N., Dayakar P., Resource optimization in construction project, International Journal of Applied Engineering Research,V-9,I-22,PP-5546-5551,Y-2014.

5. Venkat Raman K., Dayakar P., Raju K.V.B.,An experimental study on effect of cone diameters in penetration test on sandy soil, International Journal of Civil Engineering and Technology,V-8,I-8,PP-1581-1588,Y-2017.

6. Saritha B., Chockalingam M.P.,Photodradation of malachite green DYE using TIO2/activated carbon composite,International Journal of Civil Engineering and Technology,V-8,I-8,PP-156-163,Y-2017

7. Shendge R.B., Chockalingam M.P., Saritha B., Ambica A.,Swat modelling for sediment yield: A case study of Ujjani reservoir in Maharashtra, India,International Journal of Civil Engineering and Technology,V-9,I-1,PP-245-252,Y-2018

8.Chockalingam M.P., Balamurgan V.,Modernisation of an existing urban road-sector in Chennai, a case study report,International Journal of Civil Engineering and Technology, V-8,I-8,PP-1457-1467,Y-2017

9. Saritha B., Chockalingam M.P.,Adsorption study on removal of basic dye by modified coconut shell adsorbent, International Journal of Civil Engineering and Technology,V-8,I-8,PP-1370-1374,Y-2017

10. Saritha B., Chockalingam M.P.,Adsorptive removal of heavy metal chromium from aqueous medium using modified natural adsorbent,International Journal of Civil Engineering and Technology,V-8,I-8,PP-1382-1387,Y-2017

11. Chockalingam M.P., Palanivelraja S.,Retrospective analysis of a theoretical model used for forecasting future air quality near the north Chennai thermal power plant,International Journal of Civil Engineering and Technology, V-8,I-8,PP-1457-1467,Y-2017

12. Saritha B., Chockalingam M.P.,Photodegradation of methylene blue dye in aqueous medium by $\mathrm{Fe}-\mathrm{AC} / \mathrm{TiO} 2$ Composite,Nature Environment and Pollution Technology,V-17,I-4,PP-1259-1265,Y-2018 13. Shendge R.B., Chockalingam M.P., Kaviya B., Ambica A.,Estimates of potential evapotranspiration rates by three methods in upper Bhima Basin, In Maharashtra, India,International Journal of Civil Engineering and Technology,V-9,I-2,PP-475-480,Y-2018

14. Shendge R.B., Chockalingam M.P.,The soil and water assessment tool for Ujjani Reservoir,International Journal of Mechanical Engineering and Technology,V-9,I-2,PP-354-359,Y-2018

15. Shendge R.B., Chockalingam M.P.,A review on soil and water assessment tool,International Journal of Mechanical Engineering and Technology,V-9,I-2,PP-347-353,Y-2018

16. Sachithanandam P., Meikandaan T.P., Srividya T.,Steel framed multi storey residential building analysis and design,International Journal of Applied Engineering Research,V-9,I-22,PP-5527-5529,Y-2014

17. Meikandaan T.P., Ramachandra Murthy A.,Study of damaged RC beams repaired by bonding of CFRP laminates,International Journal of Civil Engineering and Technology,V-8,I-2,PP-470-486,Y-2017

18. Meikandaan T.P.,

Ramachandra Murthy

A.,Retrofittng of reinforced concrete beams using GFRP 
overlays,International Journal of Civil Engineering and Technology,V-8,I-2,PP-423-439,Y-2017

19. Meikandaan T.P., Ramachandra Murthy A.,Flexural behaviour of RC beam wrapped with GFRP sheets,International Journal of Civil Engineering and Technology,V-8,I-2,PP-452-469,Y-2017

20. Meikandaan T.P., Murthy A.R.,Experimental study on strengthening of rc beams using glass Fiber,International Journal of Civil Engineering and Technology,V-9,I-11,PP-959-965,Y-2018

21. Meikandaan T.P., Hemapriya M.,Use of glass FRP sheets as external flexural reinforcement in RCC Beam,International Journal of Civil Engineering and Technology,V-8,I-8,PP-1485-1501,Y-2017

22. Saraswathy R., Saritha B.,Planning of integrated satellite township at Thirumazhisai,International Journal of Applied Engineering Research,V-9,I-22,PP-5558-5560,Y-2014

23. Saritha B., Ilayaraja K., Eqyaabal Z.,Geo textiles and geo synthetics for soil reinforcement,International Journal of Applied Engineering Research,V-9,I-22,PP-5533-5536,Y-2014

24. Ambica A., Saritha B., Changring G., Singh N B., Rajen M., Salman Md.,Analysis of groundwater quality in and around Tambaram taluk, Kancheepuram district,International Journal of Civil Engineering and Technology,V-8,I-8,PP-1362-1369,Y-2017

25. Arunya A., Sarayu K., Ramachandra Murthy A., Iyer N.R.,Enhancement of durability properties of bioconcrete incorporated with nano silica,International Journal of Civil Engineering and Technology,V-8,I-8,PP-1388-1394,Y-2017

26. Ilayaraja K., Krishnamurthy R.R., Jayaprakash M., Velmurugan P.M., Muthuraj S.,Characterization of the 26 December 2004 tsunami deposits in Andaman Islands (Bay of Bengal, India),Environmental Earth Sciences, V-66,I-8,PP-2459-2476,Y-2012

27. Ilayaraja K.,Morphometric parameters of micro watershed in Paravanar sub-basin, Cuddalore District,International Journal of Civil Engineering and Technology,V-8,I-8,PP-1444-1449,Y-2017

28. Ilayaraja K., Singh R.K., Rana N., Chauhan R., Sutradhar N.,Site suitability assessment for residential areas in south Chennai region using remote sensing and GIS techniques,International Journal of Civil Engineering and Technology,V-8,I-8,PP-1468-1475,Y-2017

29. Ilayaraja K., Reza W., Kumar V., Paul S., Chowdhary R.,Estimation of land surface temperature of Chennai metropolitan area using Landsat images,International Journal of Civil Engineering and Technology, V-8,I-8,PP-1450-1456,Y-2017

30. Chitra R.,Experimental study on beam using steel fiber and latex,International Journal of Civil Engineering and Technology,V-8,I-8,PP-1395-1403,Y-2017

31. Chitra R.,Analysis of traffic and management at Kovilambakkam intersection,International Journal of Civil Engineering and Technology,V-8,I-8,PP-1433-1443,Y-2017

32. Aswathy M.,Experimental study on light weight foamed concrete,International Journal of Civil Engineering and Technology,V-8,I-8,PP-1404-1412,Y-2017

33. Aswathy M.,Wastewater treatment using constructed wetland with water lettuce (Eichornia Crasipies),International Journal of Civil Engineering and Technology,V-8,I-8,PP-1413-1421,Y-2017

34. Kiruthiga K., Anandh K.S., Gunasekaran K, Assessment of influencing factors on improving effectiveness and productivity of construction engineers, 2015, International Journal of Applied Engineering Research, V - 10,I -17,p -13849-13854

\section{AUTHORS PROFILE}

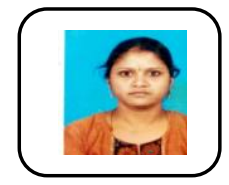

R.Chitra Assistant Professor, Department of Civil Engineering, Bharath Institute of Higher Education and Research, Chennai, India

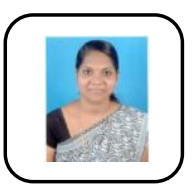

S.Thendral ,Assistant Professor, Department of Civil Engineering, Bharath Institute of Higher Education and Research, Chennai, India

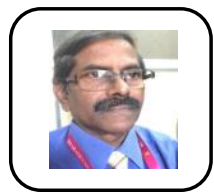

Dr.S.J.Mohan Professor, Department of Civil Engineering, Bharath Institute of Higher Education and Research, Chennai, India 